\section{Nena Židov}

Slovene Ethnographic Museum

Ljubljana

nena.zidov@etno-muzej.si
DOI $\quad 10.32458 /$ ei.26.7

UDK 069:39](497.4):616.2-036.21

Review paper

Received: $25^{\text {th }}$ May 2021

Accepted: $8^{\text {th }}$ June 2021

\title{
Slovenian Ethnologists, Cultural Anthropologists and the Slovene Ethnographic Museum in the time of COVID-19 Pandemic
}

\begin{abstract}
The article outlines the reactions of Slovenian ethnologists and cultural anthropologists to the COVID-19 pandemic in the field of research and pedagogical work at the Department of Ethnology and Cultural Anthropology of the Faculty of Arts of the University of Ljubljana. Special attention was paid to the impact of the pandemic on the work of the Slovene Ethnographic Museum in Ljubljana.
\end{abstract}

Keywords: Slovenia, pandemic, COVID-19, way of life, research, museums, Slovene Ethnographic Museum

\section{INTRODUCTION}

In Slovenia, the new Coronavirus outbreak was declared an epidemic on the $12^{\text {th }}$ March 2020 and it lasted until $15^{\text {th }}$ May, when Slovenia was the first European country to declare an end to the epidemic. The epidemic was declared once again on $19^{\text {th }}$ October and it is still ongoing at the time of writing of this paper. The virus, which has so far appeared in Slovenia in three waves, affects, as elsewhere in the world, many areas of life of both individuals and the society as a whole. It has become the subject of research in various sciences. Ethnologists and anthropologists play an important role in exploring human behaviour (Muršič 2020: 226). The entire ethnological and anthropological community in Slovenia reacted quickly to the pandemic, both the researchers employed at the Research Centre of the Slovenian Academy of Sciences and Arts (ZRC SAZU) and the lecturers at the Department of Ethnology and Cultural Anthropology at the Faculty of Arts, University of Ljubljana. The pandemic has had 
a profound impact on the cultural sector (for Southeast Europe, see Primorac 2021) which includes museums. Ethnologists and cultural anthropologists employed at the Slovene Ethnographic Museum (SEM) responded to the pandemic as museologists and our basic education in connection with ethnology and cultural anthropology was also significant. In this text I am going to present the way in which Slovenian ethnologists and cultural anthropologists involved in research and pedagogical institutions responded to this pandemic, and I am going to present in more detail the impact of the pandemic on the work of the SEM.

\section{SLOVENIAN ETHNOLOGIST AND CULTURAL ANTHROPOLOGIST IN THE TIME OF THE COVID-19 PANDEMIC}

At the beginning of April 2020, the Slovene Ethnological Society and the Institute of Slovenian Ethnology ZRC SAZU launched a participatory blog "Everyday Life: Ethnological Records", ${ }^{1}$ which was intended for reflections and discussions on how to live through or survive the quarantine period and wider social issues concerning COVID-19. By mid-June 2020, turnout was high, in the sections "About Everyday Life", "Reflections on Society" and "Impressions" at least one post per day was published and then the number of posts slightly declined. By the $5^{\text {th }}$ October, 162 posts were collected, which included photographs. Sophomores at the Department of Ethnology and Cultural Anthropology joined in the creation of the blog. During self-isolation they wrote diaries and published them in the form of short essays on the blog. As a part of the mandatory practice, several students collected various materials in connection with life during the pandemic. Some prepared records on the collected materials for "Everyday Life". The blog was also reported by the media. (Poljak Istenič and Babič 2020: 82-83) At the beginning of March, Naško Križnar, a retired researcher at the Institute of Slovenian Ethnology ZRC SAZU, invited members of the Slovene Ethnological Society to collect photos of everyday life during quarantine. About 600 photographs were collected (Križnar et al. 2020: 84). In April 2020, Barbara Turk Niskač from the Institute of Slovenian Ethnology ZRC SAZU, using an online survey, collected data on the impact of the pandemic on children's daily lives and family life (2020).

On the $19^{\text {th }}$ May, the Department of Ethnology and Cultural Anthropology organised an online symposium "Everyday Life during the Epidemic". The symposium was divided into thematic units "Epidemic and Health", "The Society in an Epidemic, an Epidemic in the Society", "Ethnography Between Four Walls" and "Mobility and Physical Inactivity during the Pandemic" (Veselinovič 2020). Within the section "Ethnography Between Four Walls", two papers in connection with the work of Slovenian museums during the epidemic were presented. Students of the Department of Ethnology and Cultural Anthropology presented the results of a study on the work of thirty museums in Slovenia during the first lockdown. The research was carried out within the framework of remote teaching process. The SEM Director at the time, Tanja Roženbergar,

1 https://vsakdanjik.zrc-sazu.si (visited on $15^{\text {th }}$ April 2021). 
presented the work of the Museum during the period in which it was closed to visitors (Veselinovič 2020: 108).

In the practical classes of the course "Ethnology of Slovenia 3", in the academic year 2020/2021, students at the Department of Ethnology and Cultural Anthropology were exploring the effects of the Coronavirus pandemic and related measures to celebrations and holidays. The collected materials (photographs, illustrative materials, audio-visual recordings, etc.) are a part of the collection The Festive Year of the Slovenes in time of the COVID-19. ${ }^{2}$ The project was reported on the $24^{\text {th }}$ May 2021 during an online event titled The Festive Year of the Slovenes in Coronavirus Pandemic: "Notes and Impressions".

Anthropologist Dan Podjed, a researcher at the Institute of Slovenian Ethnology ZRC SAZU, posted about it on Facebook, LinkedIn, Instagram and Twitter from March to April 2020 about what the daily life of him and his family was like during the quarantine (Podjed 2020a: 113). His records during the quarantine and the comments on his writings were published in the book "Anthropology Between Four Walls" (Podjed 2020b) in the same year. Some ethnologists and cultural anthropologists have frequently been appearing in the media concerning COVID-19 and the measures to fight the pandemic, especially Dan Podjed and the professor Rajko Muršič from the Department of Ethnology and Cultural Anthropology.

The topic of the pandemic was also addressed in the "Bulletin of the Slovene Ethnological Society", in the $2^{\text {nd }}$ issue, published at the end of 2020, in which a part of the texts was dedicated to COVID-19. The texts show that ethnologists and cultural anthropologists from the ranks of researchers, professors, museologists, among others, have responded to the challenges and changes in daily life as a result of the pandemic (Ličen and Poljak Istenič 2020). Scientific texts published in the previously mentioned Bulletin, as well as in the journal Ethnologist from 2020, have already reflected on the impact of the pandemic, if not thematically, then in the methodology of work. During the pandemic, ethnologists and anthropologists had to replace the method of participation by direct contact with people with "remote ethnography" method, using, inter alia, digital methods (see Podjed 2021).

In the continuation of the text, I am going to present in more detail the response of the SEM in Ljubljana to opportunities provided in the pandemic.

\section{SLOVENE ETHNOGRAPHIC MUSEUM IN THE COVID-19 PANDEMIC}

\section{MUSEUMS AND THE CORONAVIRUS CRISIS}

The pandemic declared by the World Health Organisation on the $11^{\text {th }}$ March 2020 has had unforeseen effects on the work of museums around the world. If museums wanted

2 http://www.etnoinfolab.org/collections?collection_id = 31 (visited on the $9^{\text {th }}$ May 2021). 
to continue carrying out their tasks, they had to react very quickly to the new situation. Some conditions were more or less the same for all the museums (e. g. the loss of direct contact with the visitors, work of professional staff from home at the time of museum closure, reaching visitors "remotely" ...). Many museums have faced a loss of ticket sale revenue. Among the museums that were heavily financially dependent on their own resources, there was a fear of permanent museum closure or the need to sell some of the collections in order to survive. Some museums had to lay off a part of their staff, with external museum collaborator jobs being the most severely affected. Museums that are fully or largely funded by public funds or the local community were certainly in the most favourable position. Even after the reopening, when the museums had to comply with all the safety measures, the number of visitors was not comparable with that before the pandemic.

Museums have been assisted as quickly as possible through analysis of the situation and advice for working in new opportunities by international organisations dealing with culture and in particular with museums such as UNESCO (UNESCO 2000; UNESCO 2001), ICOM (International Council of Museums) (ICOM 2020a; ICOM 2020b) and NEMO (Network of European Museum Organisations) (NEMO 2020; NEMO 2021). National museum associations also provided assistance. In Slovenia, the Slovenian Museum Association (SMS) conducted a survey among 48 museums and galleries between the $7^{\text {th }}$ and the $20^{\text {th }}$ April. In addition to reviewing the situation as a result of the pandemic, the SMS has also prepared proposals to address its consequences. ${ }^{3}$ In 2020, ICOM Slovenia dedicated the December issue of "ICOM News" magazine to museums and COVID-19.

\section{COLLECTING JOKES IN THE SEM}

The most talked about project by the SEM during the pandemic is undoubtedly the collection of jokes. On the $20^{\text {th }}$ March 2020, we started collecting jokes concerning Coronavirus and the situation in which we found ourselves as a consequence of it. We considered jokes as a medium and source for discovering the experience of everyday life in special living conditions. Due to the ban on socialising, during the first lockdown in Slovenia, jokes were shared by e-mail, social media and text messages, to name a few. A special e-mail address vici.semuzej@gmail.com was created at the museum and we selected an editorial board ${ }^{4}$ that collected jokes and made a selection of the best ones, which it published on the website of the museum (Koren Usenik et al. 2020: 11). The editorial board had a challenging task of selecting the jokes because not all of them were suitable for publication. Jokes that we received in Croatian, Serbian, Bosnian, English... were published in the original language and translated into Slovene. Most of the jokes were about quarantine, self-isolation, gender relations, banning move-

3 http://www.sms-muzeji.si/ckfinder/userfiles/files/Anketa\%20SMS\%20COVID19.pdf (visited on the 13 ${ }^{\text {th }}$ May 2021).

4 Documentarian Miha Špiček, librarian Gregor Ilaš M.Sc., curators Adela Pukl M.Sc., Polona Sketelj M.Sc. and Tanja Roženbergar Ph.D., who was the Director at the time. 
ment between municipalities, working from home, remote learning, with some dark humour and political jokes. Between March and September 2020, we received more than a thousand jokes (Ilaš et al. 2020: 223).

And the selection of the top five jokes was first published on the $23^{\text {rd }}$ March 2020. Until the end of the epidemic in Slovenia, on the $15^{\text {th }}$ May, we published them daily. After the declaration of the end of the epidemic and upon the return of people to the so-called normal life, the number of jokes sent began to decline, so we started with weekly releases. The number of jokes received increased again in September, upon the beginning of the school year, when we continued to publish weekly selections (Ibid.). One of the goals of collecting and publishing jokes was to take the weight off people and help them survive the period of the Coronavirus crisis, which was especially difficult during the first period of the declaration of the epidemic. The objective has been met, which is evident from the fact that the Museum has received a lot of positive feedback from the users, and on the museum website the most visited section was the one with humour. The project of collecting jokes was also very popular in the Slovenian media. Following the Slovenian Press agency's announcement, many other media reported the news, museum representatives reported on the project on radio and television and print and digital media reported on the project (Ibid.: 224).

The project has resonated beyond Slovenia. In addition to some foreign media (e.g. RTV Serbia and Al Jazeera Balkans) (Ibid.), it also found its place at the House of European History in Brussels. At the beginning of 2020, as a part of the project "History in the Making: Documenting COVID-19", the Museum dealing with the history of the European continent started collecting records on life in Europe during the pandemic. ${ }^{5}$ The SEM was invited to the project led by Ljubljana Tourism with the collected jokes. Five Ljubljana-based cultural institutions prepared an online exhibition on the digital platform Kunstmatrix, where they presented their ways of documenting "the times of Coronavirus" (Ibid.: 224-225). In collecting jokes, we co-operate with the Institute of Slovenian Ethnology ZRC SAZU.

On Summer Museum Night, the 20 June 2020, (when the epidemic measures were no longer in force in Slovenia), the SEM opened the exhibition "Coronavirus Humour: Jokes during the COVID-19 Epidemic" with a selection of jokes collected between the $12^{\text {th }}$ March and $31^{\text {st }}$ May. The authors were Miha Špiček and Adela Pukl (2020). The exhibition, which was open until the $6^{\text {th }}$ September (Ibid.), presented the topics that most often appeared in jokes: yeast, toilet paper, teaching and remote work, restriction of movement between municipalities, celebrations and protective equipment (Koren Usenik et al. 2020: 11). During the second wave of the epidemic, the number of jokes sent decreased slightly, so on the $9^{\text {th }}$ November 2020 , on our website we invited the visitors to send them again. ${ }^{6}$ The $70^{\text {th }}$ selection of jokes was published on the $7^{\text {th }}$ May 2021 on the SEM website.

5 https://historia-europa.ep.eu/sl/zgodovina-v-nastajanju-dokumentiramo-covid-19) (visited on the $17^{\text {th }}$ April 2021).

6 https://www.etno-muzej.si/sl/novice/povabilo-k-zbiranju-vicev-ali-koronski-humor-jesen-2020 (visited on the $12^{\text {th }}$ May 2021). 


\section{COLLECTING STORIES FROM THE TIME OF THE COVID-19 PANDEMIC AT THE SEM}

When we closed the Museum on the $13^{\text {th }}$ March 2020 due to the declaration of the epidemic, we thought about how to involve the visitors, i.e. the users, in the museum activities. In connection with the permanent exhibition "I, We and Others: Images of My World", the project "WHO AM I in this time of the pandemic?" ("KDO SEM v času pandemije?") was created. At the beginning of April, we invited the visitors to the museum website to think about who they are during the pandemic, who they miss the most in this moment, what new things they do or what they do differently when they are forced to stay at home, what new things has the time of the Coronavirus brought them and what it has taken them away from them, how their view of the world has changed and what in their opinion will be different after the pandemic. We invited all age groups to participate (Koren Usenik 2020: 216-217). By autumn 2020, nine individuals from different parts of Slovenia had responded to our invitation by sending us two photography projects, a story and five poems. The students of the Vič Grammar School in Ljubljana responded as a group, who published their contributions (thoughts, poems, texts, stories, memes and photographs) created within the English language course in an electronic publication titled "Kdo sem v času pandemije // Who am I in this time of the pandemic" (Perne 2020). The publication and other contributions have been published on the museum website ${ }^{7}$ (find out more about the project in Koren Usenik 2020).

\section{SEM AS A CO-ORDINATOR FOR THE SAFEGUARDING OF THE INTANGIBLE CULTURAL HERITAGE}

The SEM also responded to the pandemic in its role as the national co-ordinator for the safeguarding of the intangible cultural heritage. On the $7^{\text {th }}$ May 2020, UNESCO launched an online platform on the effects of COVID-19 on intangible cultural heritage ${ }^{8}$ and invited the States Parties to the Convention for the Safeguarding of the Intangible Cultural Heritage to report on the state of intangible heritage in their countries. As a co-ordinator, the SEM has submitted several examples of adaptation of intangible cultural heritage to pandemic conditions in Slovenia (Easter dances and games in Metlika, celebration of the $1^{\text {st }}$ May, The Path of Remembrance and Comradeship in Ljubljana) ${ }^{9}$ (Židov et al. 2020). UNESCO's $14^{\text {th }}$ annual meeting of experts on the intangible cultural heritage of Southeast Europe, held online on the $26^{\text {th }}$ June 2020, was also dedicated to issues in connection with intangible cultural heritage while it was "kept on mute" due to COVID-19. The representatives of the Museum participated

7 https://www.etno-muzej.si/sl/novice/kdo-sem-v-casu-pandemije-zbiramo-misli-razmisljanja-verze-zgodbe (visited on the $5^{\text {th }}$ May 2021).

8 https://ich.unesco.org/en/news/unesco-launches-platform-on-living-heritage-and-the-covid-19-pandemic-13263 (visited on the $12^{\text {th }}$ March 2021).

9 https://ich.unesco.org/en/living-heritage-experience-and-covid-19-pandemic-01124?id=00169 (visited on the $16^{\text {th }}$ May 2021). 
in the meeting through a presentation of some epidemiologically adapted forms of implementation of elements of intangible cultural heritage entered in the National Register of the Intangible Cultural Heritage. The representatives of the Museum continue monitoring the impact of the pandemic on the elements entered in the national register and we are considering conducting a survey on the impact of COVID-19 on the registered elements and their bearers.

\section{DIGITISATION AND INCREASED ONLINE PRESENCE OF THE SEM}

As is the case with most museums (with Internet access) in the world, in Europe and in Slovenia, we in the SEM have further strengthened our presence on the Internet, due to the pandemic and the consequential multiple closures of the Museum. Fortunately, we had digitised a large proportion of the items even before the pandemic and among the employees we have people equipped with the necessary knowledge for digitisation and online presence. Upon the first closure of the museum ( $13^{\text {th }}$ March - $5^{\text {th }}$ May), we started intensively complementing the digital content and increasing our online presence. We have also become more active on social media Facebook, Instagram and Twitter. Upon the first closure, when most employees worked from home, to keep in touch with our visitors and the general public, we opened a new subpage on the museum website, "SEM from home", ${ }^{10}$ where we began to offer various facilities: virtual strolls through current and past exhibitions, audio materials from exhibitions, collections of objects and photographs held at the SEM, films produced by the SEM and digital lessons for education. In addition to the content already uploaded on YouTube, we added guides to some of the past exhibitions. ${ }^{11}$ In order to introduce visitors to the work of the restorer, which is usually neglected, we added a new section titled "Among the Restorers". ${ }^{12}$

Furthermore, we emphasised digital access to the museum magazine "Ethnologist" and the digital library and some of our publications have been digitised. In April, we started presenting stories about museum objects and their wider contexts on the subpage "SEM with stories"13 (Poljak Istenič et al. 2020: 94). During the period from March to May 2020, the Museum offered more than 25,000 items of digital content to visitors on its website, and more than 100,000 page views were recorded (Koren Usenik et al. 2020: 10).

We were very active also in the Facebook page of the Museum where we announced and reported on museum events. We presented stories about museum objects. Following the annual cycle, we presented annual holidays, customs and related items and published photos and greeting cards from the Documentation of the SEM. We had live

10 https://www.etno-muzej.si/sl/sem-od-doma (visited on the $10^{\text {th }}$ May 2021).

11 https://www.youtube.com/user/etnomuzej/playlists (visited on the $6^{\text {th }}$ May 2021).

12 https://www.etno-muzej.si/med-restavratorji (visited on the $8^{\text {th }}$ April 2021).

13 https:// etno-muzej.si/sl/sem-z-zgodbami-predmetov (visited on the $6^{\text {th }}$ April 2021). 
streaming from exhibitions and exhibition openings, we presented objects and collections, we gave lectures and read fairy tales to children. We informed the visitors about the new elements entered in the Register of the Intangible Cultural Heritage and we held online workshops. In 2021, we started posting videos on Facebook every first day of the month with the main character Little Master presenting the work of various craftsmen and handicrafts (making paper flowers, decorating Easter eggs, lace making).

The pandemic has disrupted the work of the Museum on the international project Taking Care. We had to shift the planned conferences online, as well as interviews with the Indian, Kanika Gupta, an activist at the residence, who has (not yet) been able to come to Slovenia due to the pandemic. The fifth "Ethnobotany Seminar" titled "Picking - Between Instinct and Culture" was also held online on the $20^{\text {th }}$ May 2021.

\section{EXHIBITION ACTIVITY DURING THE COVID-19 PANDEMIC}

Due to the pandemic, some exhibitions have been extended, others have been postponed or transferred to the Internet. Due to the closure of the museum or the limitation of the number of visitors, the opening ceremony of exhibitions has also changed. When the museum reopened in May 2020, under the motto "With you Again", we complied with all the health regulations, we took care of the safety of both visitors and employees. A special effort was made to attract the audience we lost during the lockdown. In order to remind the passers-by of the reopening of the museum, we wrote selected jokes on billboards in front of the entrance to the Museum. The travelling exhibition of the Ethnographic Museum from Zagreb, Croatia, "Children Toys of Croatia between Tradition and Modernity", which we opened on the $20^{\text {th }}$ February, unfortunately, could not be seen by the visitors while the Museum was closed. In order to attract attention of as many people as possible after the reopening and attract children to the exhibition, we drew games on the floor in front of the Museum that children play outdoors (hopscotch and snail hopscotch). Despite the efforts, the number of visitors was, of course, much lower than before the pandemic. In March 2020, a visit by curators and two restorers from China was planned to help us restore the Chinese decorative room divider from our collection, which we were planning to exhibit after the restoration, but the visit was postponed due to the pandemic. In August 2020, the SEM joined the action of the Slovenian Museum Association referred to as "Forward to the Past", which strived to encourage more visits to museums and galleries as safe spaces during the COVID-19 pandemic through museum events and social media.

Due to the second wave of the epidemic in Slovenia, museums closed again in November. In December, we thought about how to offer the passers-by at least a touch of the New Year's atmosphere. Through "Heritage Caught in the Light of the Window", we invited visitors to visit the Museum from the outside. In the windows (illuminated in the evening) on the façade of the Museum, the passers-by could see photographs of individual objects exhibited in the Museum. Since Saint Nicholas, Santa Claus and Grandfather Frost could not visit the children in the usual way, we placed dolls wearing their costumes on the inside of the glass wall of the Museum (like the shop 
window) to be visible from the outside, as well as a replica of Gaspari's Nativity Scene. We also presented Christmas-New Year greetings from the Documentation of the SEM on billboards in front of the entrance to the Museum.

We have also provided visitors with a tour of two smaller occasional exhibitions, "Pustni Orači Okič" (February 2021) and "300 years of Škofja Loka Passion" (MarchApril 2021). After the closure of the Museum, we moved it to the window, and after the reopening we moved it back to its original place.

Irrespective of the uncertain situation, from the $1^{\text {st }}$ October to $31^{\text {st }}$ October, we visited Trieste with the exhibition "The Sea - our Life: Unveiled Memories of the Nabrežina fisherman's family". The openings of the exhibitions were virtual during the period of the Museum closure and we streamed them directly on Facebook or the YouTube channel of the Museum. Due to the pandemic, we also paid a virtual visit to the Ethnographic Museum in Zagreb, the exhibition "Where Bees Are at Home". The opening of the exhibition took place on the $3^{\text {rd }}$ November through the YouTube channel of the SEM, and the online exhibition can be visited on the websites of both the Ethnographic Museum in Zagreb (www.emz.hr) and of the SEM (www.etno-muzej.si). The opening of the exhibition "La Doctora" was on the 20 $0^{\text {th }}$ April 2021 through YouTube channel and the events accompanying the exhibition were held online.

One form of familiarising people with the heritage during the pandemic was outdoor exhibitions. In August 2020, the SEM participated in a billboard exhibition of national museums named "Forward to the Past", which was staged on the Museum Platform in front of the SEM. The SEM presented itself on two posters with selected photographs of museum objects as a part of the Street Gallery project, which presented Ljubljana museums and galleries on posters around the city during the closure in December 2020. In May 2021, as a part of International Museum Day, the SEM participated in an outdoor poster exhibition in various locations (published also in a virtual booklet). Through the topic "The Future of Museums: Recovery and Reimagine", ICOM wanted to draw attention to the changes brought about by the pandemic and convey the message that museums are actively involved in changes, which can contribute to a fairer and a more sustainable future for the society as a whole. On International Museum Day, on the $18^{\text {th }}$ May, an exhibition of posters of national museums and galleries was opened on the same topic on the Museum Platform. It saw the participation also of the SEM and it was organized by ICOM Slovenia.

\section{RESEARCH AND COLLECTION OF MUSEUM MATERIALS DURING THE PANDEMIC}

The COVID-19 pandemic has influenced our research and provision of various materials and objects on site. Due to restrictions on movement between municipalities and regions, as well as in order to comply with social distancing, we were much less present on site. We kept in touch with people over the phone, as well as through traditional postal services and e-mails. We found ourselves in a situation that we were 
living through every day and at the same time as museologists we thought about how to save this moment for our descendants. At the SEM, we agreed that each curator would document areas of life in connection with COVID-19 and collect the materials linked with their collection. As a curator for social culture, for example, I documented the closure of shops and bars, the empty city, closed children's playgrounds, queues in front of stores, the graffiti (in connection with the COVID-19 crisis and the government), anti-government protests, adaptation of some customs (e.g. drive-in Easter food blessing) etc. Concerning objects, I collected posters reflecting the spirit of the period of COVID-19 pandemic, political posters and items relating to anti-government protests (e.g. the protestors' umbrella), protective masks expressing the belonging and attitudes of the users. During the museum closure, some curators were able to do the work that they had never had time for before the pandemic.

The period of the pandemic was also a specific personal experience for museum staff. Most of us worked from home, which resulted in the loss of direct contact with the co-workers. We held meetings using Zoom and we communicated more by phone and e-mail. We worked harder on the content that we could post on the Internet. Hence, for example, I prepared a lot of posts for the Facebook page of the Museum. Like other curators, I started using Zoom and Teams to communicate. I used applications to participate in meetings, professional conferences and to give a lecture for the students of the Department of Ethnology and Cultural Anthropology.

\section{CONCLUSION}

The situation faced during the period of the COVID-19 pandemic is a big challenge for all the museums and their staff and it has strongly marked their work. Striving to do their tasks, even if it still involved remote work, they constantly and in various ways adapt to new situations. They look for ways to continue fulfilling their social, cultural and educational role in changed circumstances, while at the same time responding to the pandemic by collecting (and some by exhibiting) diverse materials in connection with life during the pandemic. Once again, questions arose from the COVID-19 crisis for museums about their mission, role and social responsibility. The pandemic proved to be an opportune moment for museums to try new ways of working (concerning which some used to be suspicious of) to maintain accessibility and carry out their tasks (Čelik 2020: 15).

It can be said that the Slovene Ethnographic Museum did quite well in the new circumstances. Since it is financed by the state, despite the loss of its own revenue (ticket sales, renting space), its business was not threatened. It was able to adapt relatively quickly to the new "remote mode", since it had a lot of digitised content from before, as well as employees with knowledge of digitisation and online media. Curators, mainly ethnologists and cultural anthropologists, with a keen eye for the changes in the daily and festive life of people, quickly reacted to the new situation, both in terms of the functioning of the museum in unusual conditions and in documenting the "new reality" and the collection of materials in connection with it. I estimate that, despite the 
new situation, we have been doing our job well all the time. One certainly needs to take into account the fact that by working "remotely" we have not reached the visitors who for various reasons do not have Internet access.

\section{REFERENCES AND SOURCES:}

ČELIK, Matevž. 2020. "Muzeji in pandemija". ICOM News Slovenia (december): 14-15. http://www.icom-slovenia.si/fileadmin/user_upload/ICOM_2020_web.pdf (visited on $15^{\text {th }}$ January 2021).

ICOM, Museums. 2020a. Museums, Museum Professionals and COVID-19: Report. ICOM. https://icom.museum/wp-content/uploads/2020/05/Report-Museums-and-COVID-19. pdf (visited on $12^{\text {th }}$ May 2021).

ICOM, Museums. 2020b. Museums, Museum Professionals and COVID-19: Follow up Survey: Report. ICOM.https://icom.museum/wp-content/uploads/2020/11/FINAL-EN_Followup-survey.pdf (visited on $12^{\text {th }}$ May 2021).

ILAŠ, Gregor, PUKL, Adela and Miha ŠPIČEK. 2020. "Zbiranje vicev na temo koronavirusa". Etnolog 30: 222-226.

ILAŠ, Gregor, PUKL, Adela and Miha ŠPIČEK. 2020. "The Slovene Ethnographic Museum and Humour during the Corona". ICME News 91: 20-23.

KOREN USENIK, Anja. 2020. "Kdo sem v času pandemije: Projekt SEM v času koronavirusa”. Etnolog 30: 216-221.

KOREN USENIK, Anja, PUKL, Adela and Miha ŠPIČEK. 2020. "Slovenski etnografski muzej med koronakrizo". ICOM News Slovenia (december): 10-12. http://www.icom-slovenia. si/fileadmin/user_upload/ICOM_2020_web.pdf (visited on $15^{\text {th }}$ January 2021.).

KRIŽNAR, Naško et al. 2020. "Podobe iz mehurčka”. Glasnik Slovenskega etnološkega društva 60 (2): 84-93.

LIČEN, Daša and Saša POLJAK ISTENIČ. 2020. "Refleksije iz pandemije". Glasnik Slovenskega etnološkega društva 60 (2): 1.

MURŠIČ, Rajko. 2020. "Pandemic in a Globalised World: Slovenian Perspectives". Inter Faculty 10: 223-233. https://doi.org/10.15068//00162404 (visited on $28^{\text {th }}$ January 2021).

NEMO, Survey. 2020. Survey on the Impact of COVID-19 Situation on Museums in Europe: Final Report. https://www.nemo.org/fileadmin/Dateien/public/NEMO_documents/ NEMO_COVID19_Report_12.05.2020.pdf (visited on $15^{\text {th }}$ March 2021).

NEMO, Follow-up Survey. 2021. Follow-up Survey on the Impact of the COVID-19 Pandemic on Museums in Europe: Final Report. Network of European Museum Organizations. https://www. nemo.org/fileadmin/Dateien/public/NEMO_documents/NEMO_COVID19_FollowUpReport_11.1.2021.pdf (visited on $15^{\text {th }}$ March 2021).

PERNE, Anže, ed. 2020. Kdo sem v času pandemije? [Elektronski vir] = Who am I in this time of the pandemic?: Elektronski zbornik izdelkov dijakov in dijakinj. Ljubljana: Gimnazija Vič. http://gimvic.org/dejavnosti/publikacije/kdo_sem_v_casu_pandemije_zbornik.pdf (visited on $10^{\text {th }}$ May 2021). 
PODJED, Dan. 2020a. "Antropologija med štirimi stenami: Od dnevnika na obrežjih do knjige”. Glasnik Slovenskega etnološkega društva 60 (2): 113-114.

PODJED, Dan. 2020b. Antropologija med štirimi stenami: Spoznavanje družbe in sebe med pandemijo. Ljubljana: Založba ZRC.

PODJED, Dan. 2021. "Renewal of Ethnography in the Time of the COVID-19 Crisis". Sociologija i prostor 59 (219): 267-284.

POLJAK ISTENIČ, Saša et al. 2020. "Zaprti za obiskovalce, a še kako aktivni: Muzeji med pandemijo covida-19”. Glasnik Slovenskega etnološkega društva 60 (2): 94-105.

POLJAK ISTENIČ, Saša and Saša BABIČ. 2020. "Vsakdanjik: Participativni spletni dnevnik za zapise iz pandemije in po njej”. Glasnik Slovenskega etnološkega društva 60 (2): 82-83.

PRIMORAC, Jaka. 2021. "Izgubljeni prihodi i pronađena solidarnost: Utjecaj prvog vala pandemije bolesti COVID-19 na kulturni sektor u jugoistočnoj Europi”. Sociologija i prostor 59 (219): 219-237.

TURK NISKAČ, Barbara. 2020. "Vpliv epidemije na vsakdanjik otrok in družinsko življenje: Rezultati ankete aprila 2020”. Glasnik Slovenskega etnološkega društva 60 (2): 110-112.

UNESCO, Museums. 2020. Museums Around the World in the Face of Covid-19: UNESCO Report: May 2020. Paris: UNESCO. https://unesdoc.unesco.org/ark:/48223/pf0000373530 (visited on $12^{\text {th }}$ May 2021).

UNESCO, Museums. 2021. Museums Around the World in the Face of Covid-19: UNESCO Report: April 2021. Paris: UNESCO. https://unesdoc.unesco.org/ark:/48223/pf0000376729_eng (visited on $12^{\text {th }}$ May 2021).

VESELINOVIČ, Jaro. 2020. "Vsakdanje življenje med epidemijo: Simpozij Oddelka za etnologijo in kulturno antropologijo, Ljubljana in svetovni splet, 19. 5. 2020". Glasnik Slovenskega etnološkega društva 60 (2): 106-109.

ŽIDOV, Nena, JERIN, Anja and Adela PUKL. 2020. "Nesnovna kulturna dediščina v času COVIDA-19". ICOM News Slovenia (december): 20-21. http://www.icom-slovenia.si/ fileadmin/user_upload/ICOM_2020_web.pdf (visited on 15 ${ }^{\text {th }}$ January 2021).

https://ich.unesco.org/en/news/unesco-launches-platform-on-living-heritage-and-the-covid19-pandemic-13263 (visited on $16^{\text {th }}$ March 2021).

https:// etno-muzej.si/sl/sem-z-zgodbami-predmetov (visited on $6^{\text {th }}$ April 2021).

https://www.etno-muzej.si/med-restavratorji (visited on $8^{\text {th }}$ April 2021).

https://vsakdanjik.zrc-sazu.si (visited on $15^{\text {th }}$ April 2021).

https://historia-europa.ep.eu/sl/zgodovina-v-nastajanju-dokumentiramo-covid-19) (visited on $17^{\text {th }}$ April 2021).

https://www.etno-muzej.si/sl/novice/kdo-sem-v-casu-pandemije-zbiramo-misli-razmisljanja-verze-zgodbe (visited on $5^{\text {th }}$ May 2021).

http://www.etnoinfolab.org/collections?collection_id=31 (visited on $9^{\text {th }}$ May 2021).

https://www.etno-muzej.si/sl/sem-od-doma (visited on $10^{\text {th }}$ May 2021). 
https://www.etno-muzej.si/sl/novice/povabilo-k-zbiranju-vicev-ali-koronski-humor-jesen2020 (visited on $12^{\text {th }}$ May 2021).

http://www.sms-muzeji.si/ckfinder/userfiles/files/Anketa\%20SMS\%20COVID19.pdf (visited on $13^{\text {th }}$ May 2021).

https://ich.unesco.org/en/living-heritage-experience-and-covid-19-pandemic-01124?id=00169 (visited on $16^{\text {th }}$ May 2021). 